\title{
Analisys of casting defects and mechanical properties on Al-Si alloys using Bangkalan local clays as sand casting binder
}

\author{
Candi Galih Syaifullah ${ }^{1, *}$, Ayik Bela Saputra ${ }^{1}$, Shabrina Ruhyatul $\mathrm{F}^{1}$, Poppy Puspitasari ${ }^{1}$ \\ ${ }^{1}$ Department of Mechanical Engineering, Faculty of Engineering, State University of Malang, 65145 \\ Malang, Indonesia
}

\begin{abstract}
This research is aimed to know the defect of castings, tensile strength, and hardness of Al-Si alloy to the variation of binder. The research method used is descriptive quantitative research method. This beacuse the data is expressed in the form of numbers. This research uses pre-experimental research design using one-shot case study model. Based on the results of the study, it was found that most pinhole defects were owned by specimens using $90 \%$ bentonite binder that is 59 defects. Whereas the pinhole defect which is at least owned by the specimens using banngkalan local clay binder $9 \%$ that is 31 defects. The most common open grain structure defect is owned by metal casting specimens using a $9 \%$ bentonite binder, which is 81 defects. Whereas the defect of open grain structure is at least owned by the specimen result of casting of metal clad with bangkalan local clay $3 \%$ which amounted to 40 defects. The result of the research using bangkalan local clay binder of $9 \%$ has higher tensile strength than other binder. This is because the characteristic of bangkalan local clay which has a high content of calcium (Ca) is $92,81 \%$. The value of the tensile strength of the bangkalan local clay is $12,8712\left(\mathrm{~kg} / \mathrm{mm}^{2}\right)$, whereas the bentonite which is said to be the ideal binder for the mold has a tensile strength of $10,1612\left(\mathrm{~kg} / \mathrm{mm}^{2}\right)$. The highest hardness value is owned by Al-Si alloy casting specimen with bend mixture variation of bangkalan local clay $9 \%$ that is $128,033 \mathrm{HV}$. While the lowest hardness value is owned by Al-Si alloy casting foundry with $9 \%$ bentonite binder $114,4 \mathrm{HV}$.
\end{abstract}

\section{Introduction}

Science and technology of the world today is increasingly advanced and growing rapidly. Demanding the world of industry to be able to apply and develop technology in order to produce quality products. especially in the world of metal casting. According to [12] The process of metal casting is the process of manufacturing a product

\footnotetext{
*Corresponding author: galihcandi.25@gmail.com
} 
that starts from pouring molten metal into a mold cavity and then left for a while for clotting process.

Metal casting is a path taken when machining and metal formation can not be done with machining or bench work (forging). Metal casting indicator is a complicated shape and requires a high level of accuracy. Bronze casting was first performed in Mesopotamia approximately $3,000 \mathrm{BC}$, then this technique was passed on to Central Asia, China and India [12].

Examples of casting product results are numerous, just like in car parts such as; cylinder block, brake pads, crank house, cylinder sheets and so on. For casting results on machine tool components, such as machine bed, machine table and handle. All casting products are using a variety of molds. For mass-produced prints do not use sand prints whereas for complicated products and not in bulk products then sand molds are used. According to [11] wet sand mold is sand mold which still has $5 \%$ water content, while dry sand mold has no water content. Wet sand molds generally use clay binders for cheaper reasons.

The use of bentonites in sand mold mixture is not more than $9 \%$ due to the difficulty of removing castings from sand mold [11]. Usually the sand used in making molds for casting process is mixed with water and clay. The typical volume of the mixture can be $89 \%$ sand, $7 \%$ binder, and $4 \%$ water [9]. Examples of casting product results are numerous, just like in car parts such as; cylinder block, brake pads, crank house, cylinder sheets and so on. For casting results on machine tool components, such as machine bed, machine table and handle.

The focus of this study is to identify the defects of castings, tensile strength, and Al-Si alloys with variation of bentonite bentonite drops, and localized clay clays. This research is aimed to know the defect of castings, tensile strength, and hardness of Al-Si alloys on the variation of the binders. In order to select the printing sand binders then there will be no selection of binder material that is fatal on the quality of cast products.

\section{Methodology}

Research method used is descriptive quantitative research method. This is because the data is expressed in figures. This study uses pre-experimental research design by using a oneshot case study model. This research model is intended to know a group of subjects that are subject to treatment and then to measure the group. The strength of castings has been determined to be incorporated into dependent variables, ie castings, tensile strength, and Al$\mathrm{Si}$ alloys. While it is said that the experimental quantitative is due to the results of the research described by researchers based on the manipulation of free variables (in the form of bentonite variants), Molasses drops, local clay clays and all three mixtures and control variables ( $9 \%$ binder content and $5 \%$ water content).

Materials used for this study are bentonite, molasses, bangkalan local clay, silica sand and used pistons. The tools used to support the implementation of this research are tensile test engines, vickers hardness test tools, DSLR camera. In this research, the process is a macro photo of castings and conducts a real test using metal tensile test tool and vickers test tool. Before making macro photos and real testing many things to prepare, such as performing XRF testing, XRD testing, and testing of mechanical properties of printed sand, designing predetermined patterns, molding, smelting and pouring of Al-Si metal, as well as making specimens in accordance with defined standards. The characteristic to know is the mechanical properties and permeability of sand printing with local clays and the composition of the local elemental composition of clays. The data can be obtained from the results of previous similar studies.

Once the test specimen is made according to the standard and the standard of the test is determined, then the test process can be applied. The results of this testing process can be a 
tensile strength value, the Al-Si alloy hardness value and the number of defects present in the castings.

\section{Findings and Discussion}

The data generated in this research are numerical, analytical and exposure drawing which include defects in castings, tensile strength and Al-SI alloying. Testing for defective castings aims to find out how many defects are induced in each casting product on the printed sands that vary the binder. Tensile strength testing aims to determine whether there is an influence betewen the binding agent used on the ductile properties possessed by $\mathrm{Al}-\mathrm{Si}$ alloy casting. Hardness testing aims to determine the effect of binder variation on hardness on Al-Si Alloy castings.

\subsection{Analysis of Elements}

The following are the drawings and tables that explain the ressults of XRF testing on silica sand, bentonite, molasses, bangkalan local clay, and used piston. Elements contained in bangkalan local clay is Magnesium (Mg) 6\%, Calcium (Ca) 92,81\%, Ferrum (Fe) 0,24\%, Cuprum $(\mathrm{Cu})$ 0,07\%, Strontium (Sr) 0,27\%, Iterbium ( $\mathrm{Yb}$ ) 0,56\%. The highest chemical content composition in bangkalan local clay is Calcium $(\mathrm{Ca})$ of $92,81 \%$. Based on three types of chemical content similar to bentonite which is commonly used as binder and the highest value of Calcium (Ca) element, bangkalan local clay can also be used as sand binder material. Bangkalan local clay is a type of limestone or clay remaining fragments of natural stone. According to [1] said limestone is one of the most numerous groups of shoestring. While the benefits of limestone, including used for plaster, mixing brick, making cement tras, or red cement. According to [3] " The more perfect the formation of cementing agents makes the mold harder". While on the sand tied by bangkalan local clay have the content of $\mathrm{CaCO}_{3}$ reachs with water in a powder state will quickly harden and produce cementing agent with sufficient quantities.

\subsection{Analysis Fase On Bangkalan Local Clay}

The following is the result of XRD testing which aims to find out the grain size distribution in bangkalan local clay.

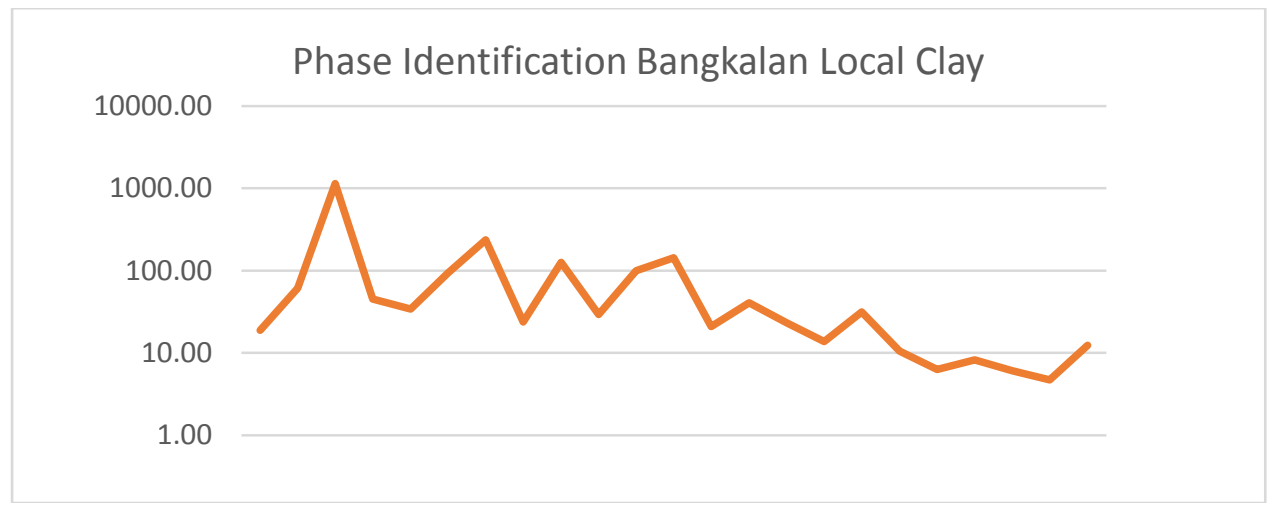

Fig. 1. Phase Identification Bangkalan Local Clay 
Based on the above picture is known that the highest peak is owned by the element Calcium ( $\mathrm{Ca}$ ) and the second highest peak is owned by Silica ( $\mathrm{Si}$ ). Both elements are elements that become a requirement to be a condition of bangkalan local clay can be used as a binder. The content of $\mathrm{CaCO}_{3}$ if it reacts with water will form a pozzolanic reaction which results in a dry state of the mold becomes very hard. According to [4] " $\mathrm{CaCO}_{3}$ when added water, the reaction will run very strongly and quickly if in powder form, calcium carbonate powder will release the heat". In addition, the bangkalan local clay crystal diameter can be known bangkalan based on the above phase diagram. Bangkalan local clay diameter of $59,87 \mathrm{~nm}$. It is known through the heighest peak being in position 30,8704 $2 \theta$ with intensity $1131,80 \mathrm{cts}, \mathrm{d}$-spacing $\AA$ equal to 2,89665 and FWHM $0,13782 \theta$. K-alpha 1 wavelenght is $1,54060 \mathrm{~K}$-Alpha 2 wavelenght 1,54443, and K-Beta wavelenght is 1,39225.

\subsection{Defects of Metal Casting}

Checking the quality of casting can be done in various ways, one of them with visual isnpection and macro photographs done by sight. In this study investigated is the aperance of the surface of the casting, various defects and how many the number of defects that ccur on the surface of the castings.

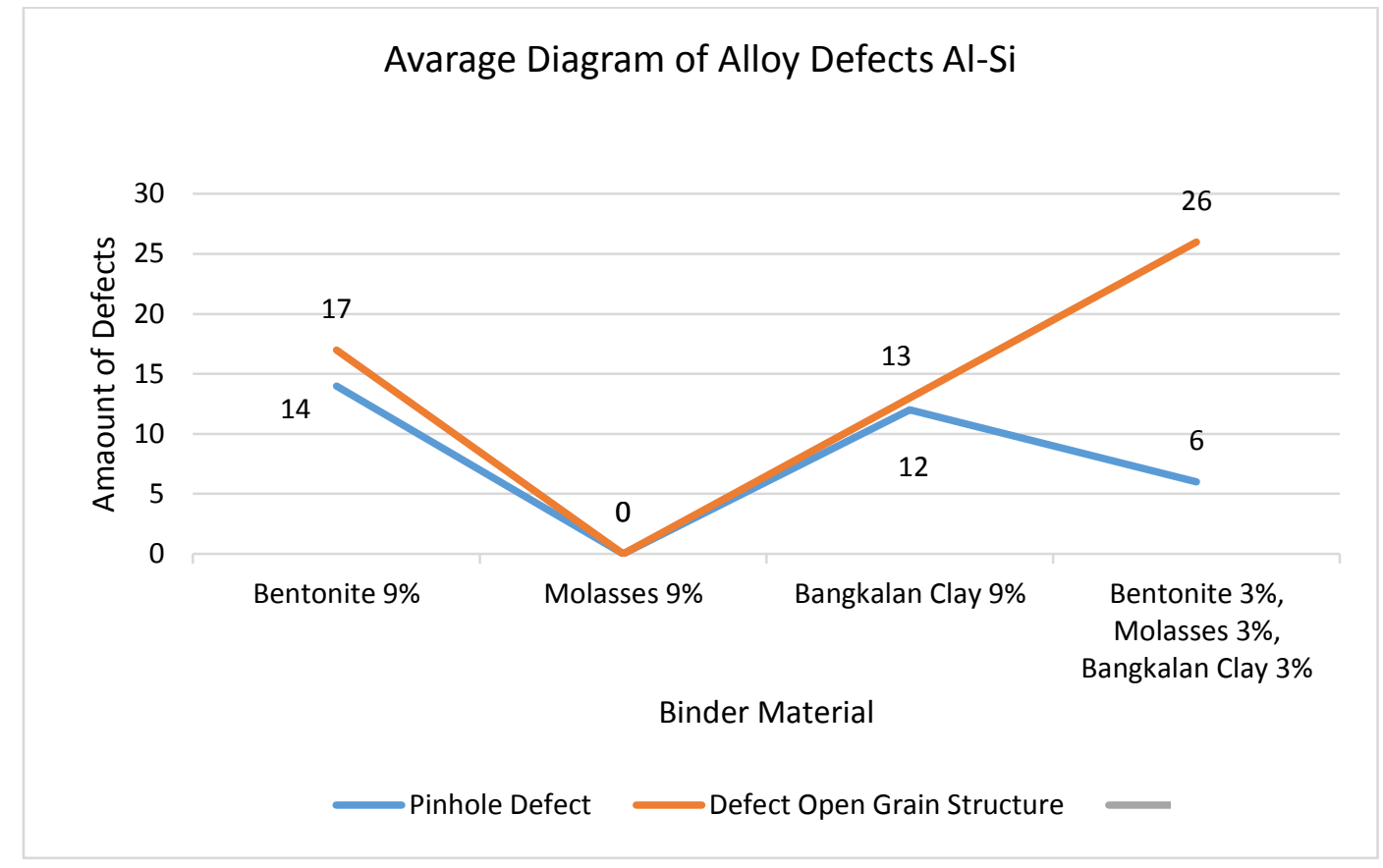

Fig. 2. Diagram Of Needle And Defects Hole Defects Open Grain Itemss Photo Of Macro Al-Si Alloys

Based on the above figure it can be seen that the pinhole defect and the open grain structure defect for bentonite percentage of $9 \%$ of the needle needle defect as much as 14 and the defect of the grain structure of the opening 17 defects. Local clay bangkalan $9 \%$ has 12 pinhole defects and defects of open grain structure 13 defects. As for the third mix of $3 \%$ each have defects of the pinhole as much as 6 defects and defects the grain structure of the opening 26 defects. The defects of open grain structures are caused by low cooling speeds, which extend in thick slices, looking like skin pores on a surface that has been 
worked with the machine [12]. An effort to prevent the defect of other open grain structures is to increase the cooling speed of using bangkalan local clay binder as a binder or as an additive. This is in according with the opinion of [2] limestone affecting the process of cooling the results of Al-Si metal casting.

\subsection{Tensile Strength of Al-Si Alloys}

Tensile testing performed showed that Al-Si casting with 9\% bentonite binder has a tensile strength with an average of $10,1612 \mathrm{~kg} / \mathrm{mm}^{2}$, while Al-Si metal casting with bangkalan local clay binder $9 \%$ has tensile strength average $12,8712 \mathrm{~kg} / \mathrm{mm}^{2}$, and Al-Si metal casting with variation of $3 \%$ bentonite binder, bangkalan local clay $3 \%$ and $3 \%$ molasses have tensile strength $11,3008 \mathrm{~kg} / \mathrm{mm}^{2}$.

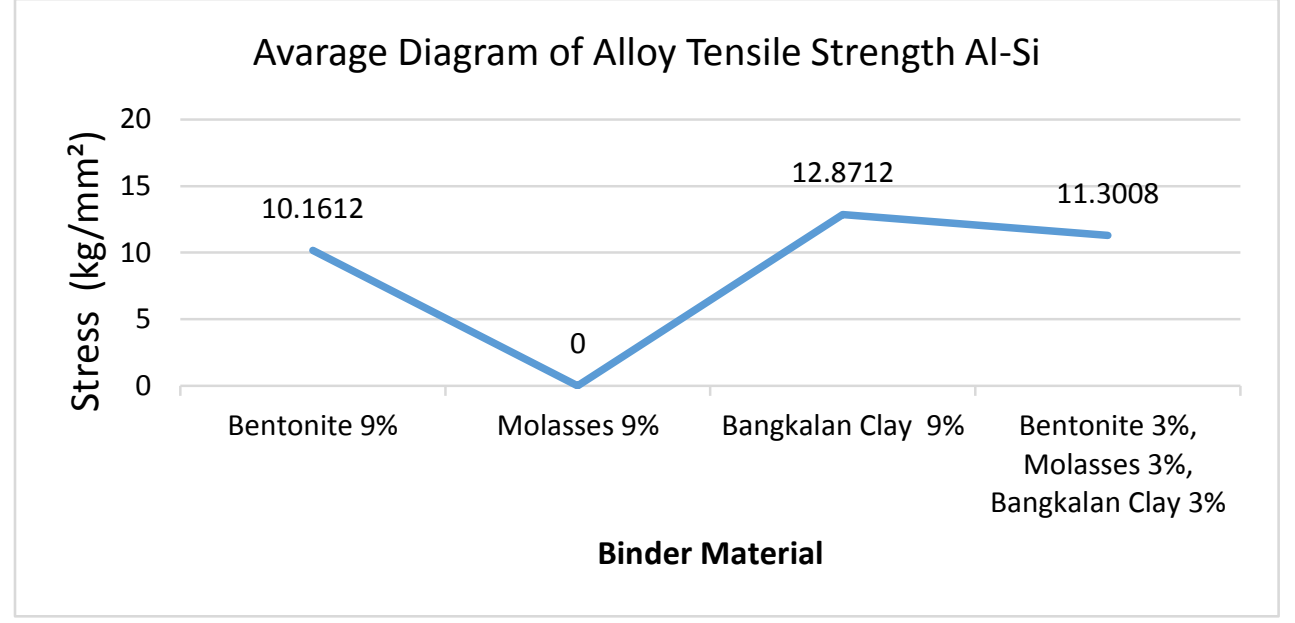

Fig. 3. Diagram Tensile Strength Of Alloy Tensile Strength Al-Si

The result of the research using bangkalan local clay binder of $9 \%$ has higher tensile strength than other binder. This is because the characteristic of bangkalan local clay which has a high content of Calcium $(\mathrm{Ca})$ is $92,81 \%$. The element of calcium can increase the tensile strength of Al-Si metals. This is in line with the research conducted by [5] who examined the analysis of castor defects, tensile strength, and hardness of Al-Si foundry with the percentage of bangkalan local clay. Where the highest tensile strength value is found in Al-Si foundry with variation of bangkalan local clay $12 \%$ with added material of $0,5 \%$ bentonite which is $11,301 \mathrm{~kg} / \mathrm{mm}^{2}$. While the lowest strength is found in Al-Si casting with variation of binder bangkalan local clay $9 \%$ that is equal to $10,843 \mathrm{~kg} / \mathrm{mm}^{2}$.

In another study conducted by [6], the value of tensile strength in silicon aluminium casting research using $10 \%$ bentonite swelling mixer and non-swelling bentonite with $10 \%$ portland cement has a low tensile strength than casting result this is using a variation of bangkalan local clay binder. On bentonite swelling $10 \%$ tensile strength value of 10,76 $\mathrm{kg} / \mathrm{mm}^{2}$ and on $10 \%$ non-swelling bentonite of $6,36 \mathrm{~kg} / \mathrm{mm}^{2}$.

The yield of tensile strength can also be affected by the amount of gas trapped in the alloy. The absorbed gas may cause defects in gas porosity. According to [8] states that the defect of porosity can be detrimental because it will reduce the mechanical strength of the casting. Another influence affecting the yield of the tensile strength of the specimen with the $9 \%$ bentonite binder variation is affected by the open grain structure defect,evident in the macro photo analysis of the open grain structure defect held by the specimens with the 
$9 \%$ bentonite binder variant being the ost numerous. In the opinion of [12] say that the low tensile strength is affected by the open grain structure defects.

\subsection{Hardness Strength of Al-Si Alloys}

Surface hardness is a term that expresses the strength of the material or its material and its resistance to wear and tear. Violence testing is done with the scale used is HV (Hardness Vickers) with diamond pyramid penetration, with style 200 grams and dwell for 10 seconds. Hardness tests were performed at 3 different point on the specimens surface.

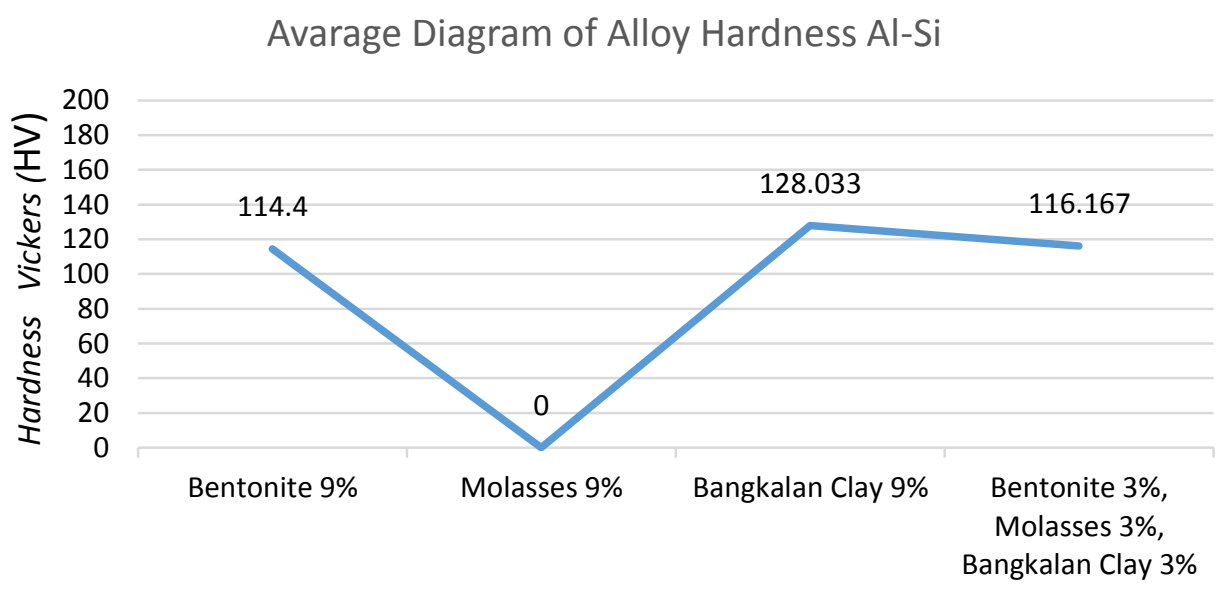

Binder Material

Fig. 4. Diagram Vickers Hardness Test Results Al-Si Metal Alloys

Based on picture it can be seen that the hardness valea in each specimen is different. Where the highest hardness is owned by Al-Sialloy casting specimens with local bending mixture variation bangkalan $9 \%$ that is $128,033 \mathrm{Hv}$. While the lowest hardness value is owned by Al-Si alloy casting foundry with $9 \%$ bentonite binder, 114,4 HV. This occurs due to the characteristics of bangkalan local clay which has a high content of calcium is $92,81 \%$. The element of calcium is usually present in limstone, and it can increase the hardness of Al-Si metals.

The statement is in line with a study conducted by [5] who examined the analysis of castor defects, tensile strength, and hardness of Al-Si foundry with the percentage of bangkalan local clay. Where the result of Al-Si metallic leaching research using bangkalan local clay $12 \%$ with the addition of $0,5 \%$ bentonite which has the highest hardness value of 131,9 HV compared with Al-Si metal casting result using bangkalan local clay $9 \%$ with the addition of bentonite $0,5 \%$ of $118,467 \mathrm{HV}$ and $6 \%$ with the addition of $0,5 \%$ bentonite of 114,2 HV. According Dwi Herdian (2015:58-59) who examines the influence of limstone mixture as a material on the poor sand against the fluidity, hardness and quality of Al-Si metal casting. Explained thet the hardness producted using rockwell hardness tester hardness with 7\% limestone composite got the highest hardness value with 52,8 HRB compared with $3 \%$ composition with hardness $47,89 \mathrm{HRB}$ and $5 \%$ with hardness 52,26 HRB. Bangkalan local clay own included i natural limestone.

In addition, the value of hardness is also influenced by permeability, good permeability capable of channeling the air in the print cavity to exit [7]. The speed of the cooling process in a sand mold is strongly influenced by the value of the permeability of the mold, 
thereforethe higher the permeability value of a sand mold increases the speed of the hot metal cooling process contained in the sand mold [10]. According to [7] permeability not only affects the hardness of the cast, the air is trapped inside the print cavity, but also affects the surface smoothness of the cast. In addition to Calcium content thet can affect the hardness of magnesium content on the bangkalan local clay of also affect the value of hardness of castings. Noor Cholis et al, (2013) that more and more magnesium elements are added, the hardness of aluminium casting results is increassing. The addition of magnesium in small amounts will have an impact on the increase in small hardness as well.

\section{Conclusion}

Most pinhole defects are owned by Al-Si alloy casting specimens with bangkalan local clay ninding variant $9 \%$ that amounted to 31 defects. While the most open grain structure defect is owned by Al-Si alloy casting specimens with $9 \%$ bentonite binder variation, which is 81 defects. Whereas the defect of open grain structure is at least owned by Al-Si Alloy casting specimens with 3\% Bangkalan local clay binder variant, which is 40 defects. The result of the research using bangkalan local clay binder of $9 \%$ has higher tensile strength than other binder. This is because the characteristic of bangkalan local clay which has a high content of calcium $(\mathrm{Ca})$ is $92,81 \%$. The value of the tensile strength of the bangkalan local clay is $12,8712\left(\mathrm{~kg} / \mathrm{mm}^{2}\right)$, whereas the bentonite which is said to be the ideal binder for the mold has a tensile strength of $10,1612\left(\mathrm{~kg} / \mathrm{mm}^{2}\right)$. The highest hardness value is owned by Al-Si alloy casting specimens with bangkalan local clay mixture variation of $9 \%$ that is 128,033 $\mathrm{HV}$. While the lowest hardness value is owned by Al-Si alloy casting foundry with $9 \%$ bentonite binder 114,4 HV. This suggests that the Ca and Mg content of the bangkalan local clay affects the defects of castings, tensile strength and hardness of Al-Si alloy metals.

\section{References}

1. Darren, et al. Jurnal Teknik Mesin Dan Ilmu Komputer. Dari http://ejournal.ukrida .ac.id/ojs/index.php/TIK/article/viewFile/1132/1355. (2016)

2. Dwi H, Anggrianto. Skripsi tidak diterbitkan. Malang: Universitas Negeri Malang. (2015)

3. Herwido, et al. Jurnal Teknik Mesin 1, 1-11. (2016)

4. Margareta, Mailinda, and Fuad. Sintesa Hydroxyapatite $\left(\mathrm{Ca}_{10}\left(\mathrm{PO}_{4}\right)_{6}(\mathrm{OH})_{2}\right)$ Berbasis Batu Kapur, Jurnal Penelitian Fisika Dan Aplikasinya (JPFA), 5, 1, pp.15-20. (2015)

5. Muhtarom, Imam. Skripsi tidak diterbitkan. Malang: Universitas Negeri Malang. (2018)

6. Pratama, Okta Angga. Skripsi tidak diterbitkan. Malang: Universitas Negeri Malang. (2017)

7. Saputra, Ayik Bela. Skripsi tidak diterbitkan. Malang: Universitas Negeri Malang. (2018)

8. Septian, Reza. Skripsi Teknik Mesin. Dari http://lib.ui.ac.id/file?file=digital/20284476-s799-porositas\%20penyusutan.pdf. (2011)

9. Shahria et al. Optimization Of Molding Sand Composition For Casting Al Alloy, 5, 3, 155-161, (2017)

10. Tarkono, Harnowo and Sewandono. Jurnal FEMA, 1, pp. 1-12. (2013)

11. Tjitro, et al. Seminar Nasional Teknik Mesin 4, pp.196-199. (2009)

12. Surdia and Chijiwa, Kenji. Jakarta: Pradnya Paramita (2000) 